\title{
Morinda citrifolia
}

\author{
National Cancer Institute
}

\section{Source}

National Cancer Institute. Morinda citrifolia. NCI Thesaurus. Code C60662.

A shrub or small tree in the family Rubiaceae. Morinda citrifolia is native to Southeast Asia but has been extensively spread by man throughout India and into the Pacific islands as far as the French Polynesian Islands. It grows in shady forests as well as on open rocky or sandy shores. It is tolerant of saline soils, drought conditions, and secondary soils. It therefore found in a wide variety of habitats: volcanic terrains, lava-strewn coasts, and clearings or limestone outcrops. It can grow up to $9 \mathrm{~m}$ tall, and has large, simple, dark green, shiny and deeply veined leaves. The plant flowers and fruits all year round. The flowers are small and white. The fruit is a multiple fruit that has a pungent odor when ripening, and is hence also known as cheese fruit or even vomit fruit. It is oval and reaches $4-7 \mathrm{~cm}$ in size. 